\title{
Neonatal Fc receptor induces intravenous immunoglobulin growth suppression in Langerhans cell histiocytosis
}

\author{
Yuka Nabeshima ${ }^{1}$, Tatsuki Kataoka ${ }^{1}$, Chiyuki Ueshima ${ }^{1}$, Narumi Saito ${ }^{1}$, Masahiro Hirata ${ }^{1}$, \\ Yusuke Takei $^{2}$, Koki Moriyoshi ${ }^{3}$, Kazuo Ono ${ }^{4}$, and Hironori Haga ${ }^{1}$ \\ ${ }^{1}$ Kyoto University Hospital \\ ${ }^{2}$ Osakafu Saiseikai Noe Hospital \\ ${ }^{3}$ National Hospital Organisation Kyoto Medical Center \\ ${ }^{4}$ Japan Red Cross Wakayama Medical Center
}

September 7, 2020

\begin{abstract}
BACKGROUND: The neonatal Fc receptor (FcRn) plays a role in trafficking $\operatorname{IgG}$ and albumin and is thought to mediate intravenous immunoglobulin (IVIG) therapy for certain diseases. IVIG can be used for the treatment of human Langerhans cell histiocytosis (LCH); however, the mechanism remains unclear. The expression and function of FcRn have not been studied in LCH. METHODS: We evaluated the expression of FcRn in pathological samples with LCH by Immunohistochemistry, and did in LCH-like cell lines by RT-PCR and immunoblotting. Cell growth assay and immunocytochemistry were employed to evaluate the FcRn function in the LCH cell line in the presence or absence of albumin in the culture medium. RESULTS: We confirmed the expression of FcRn in 26 of 30 pathological cases (86.7\%) diagnosed immunohistochemically as LCH. The expression was independent of age, gender, location, multi- or single-system, and the status of BRAFV600E immunostaining. We also confirmed the expression of FcRn mRNA and protein in the human LCH-like cell line ELD-1, but not in another LCH-like cell line PRU-1. IVIG administration suppressed albumin-dependent cell growth of mock ELD-1 cells, but not of FcRn-knockdown ELD-1 cells. FITC-conjugated albumin was taken into Rab11-positive recycle vesicles in mock ELD-1 cells, but not in FcRn-knockdown ELD-1 cells. IVIG prolonged this status in mock ELD-1 cells. CONCLUSION: ELD-1 recycled albumin via FcRn and albumin was disused for cell growth. Our results increase our understanding of the molecular mechanism of IVIG treatment of $\mathrm{LCH}$.
\end{abstract}

\section{Hosted file}

TextFile(Nabeshima et al.).doc available at https://authorea.com/users/356715/articles/ 479558-neonatal-fc-receptor-induces-intravenous-immunoglobulin-growth-suppression-inlangerhans-cell-histiocytosis

\section{Hosted file}

TableFile(Nabeshima et al.).docx available at https://authorea.com/users/356715/articles/ 479558-neonatal-fc-receptor-induces-intravenous-immunoglobulin-growth-suppression-inlangerhans-cell-histiocytosis 


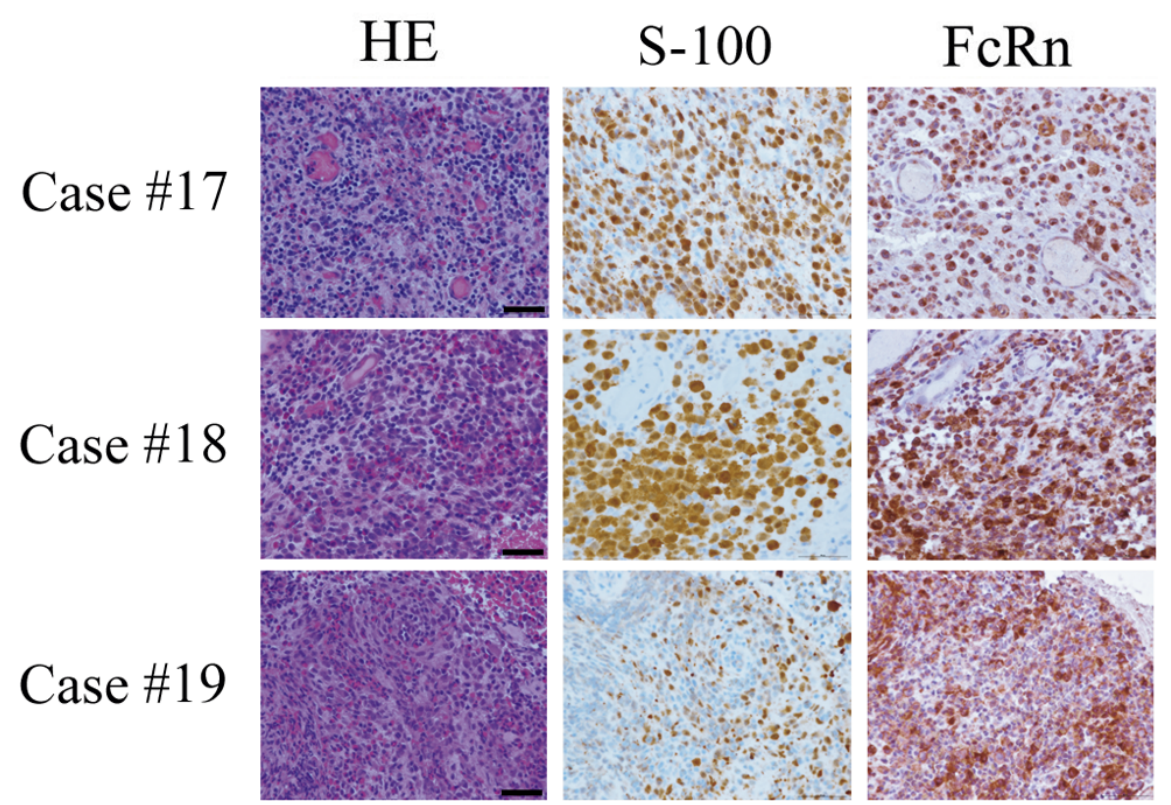

$\begin{array}{ll}\text { (A) Real time PCR } & \text { (B) Immunoblotting }\end{array}$

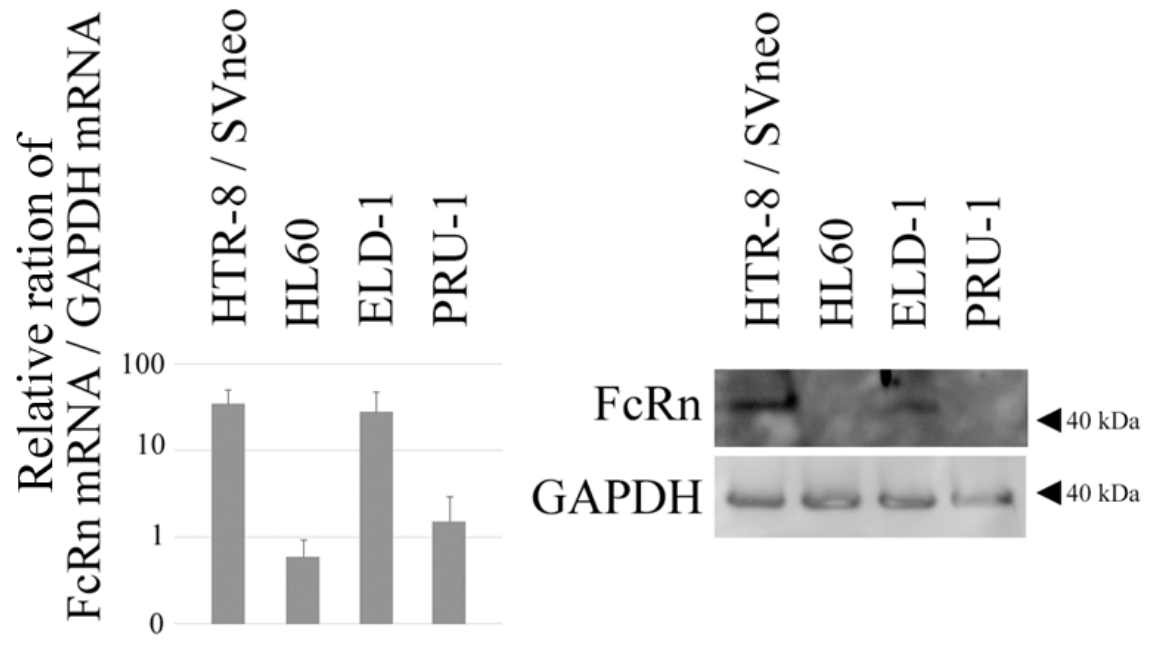

(C) Immunocytochemistry

Control IgG anti-FcRn

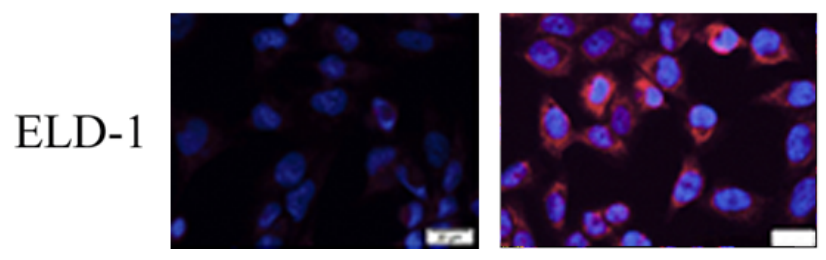




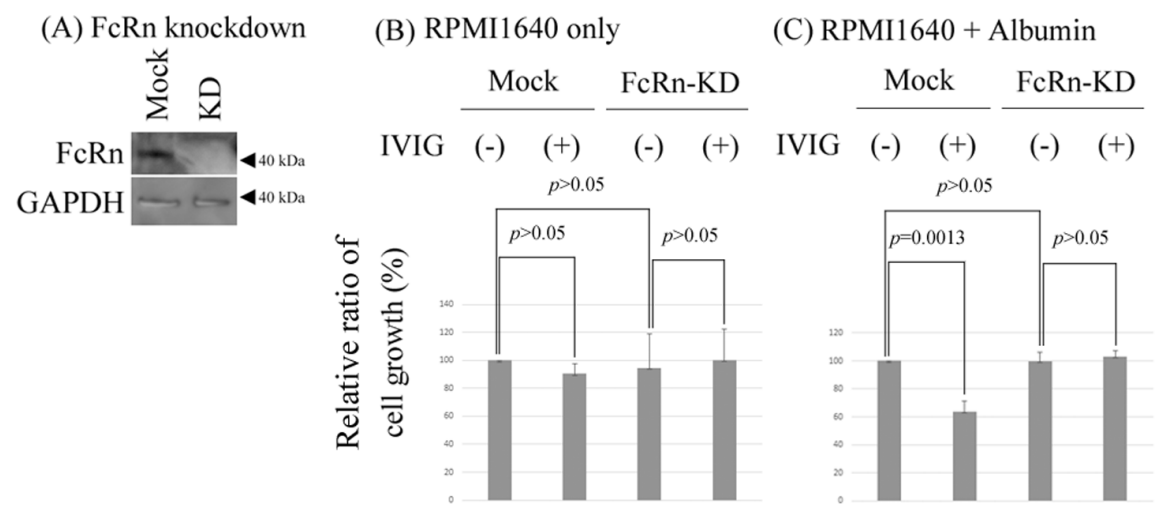

(A) Albumin uptaken by ELD-1

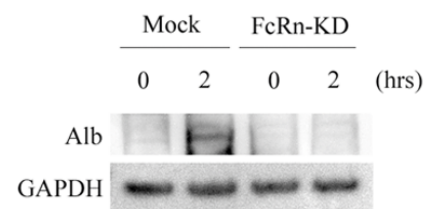

(B) Colocalization of RAB11-positive endosomes and FITC-conjugated albumin

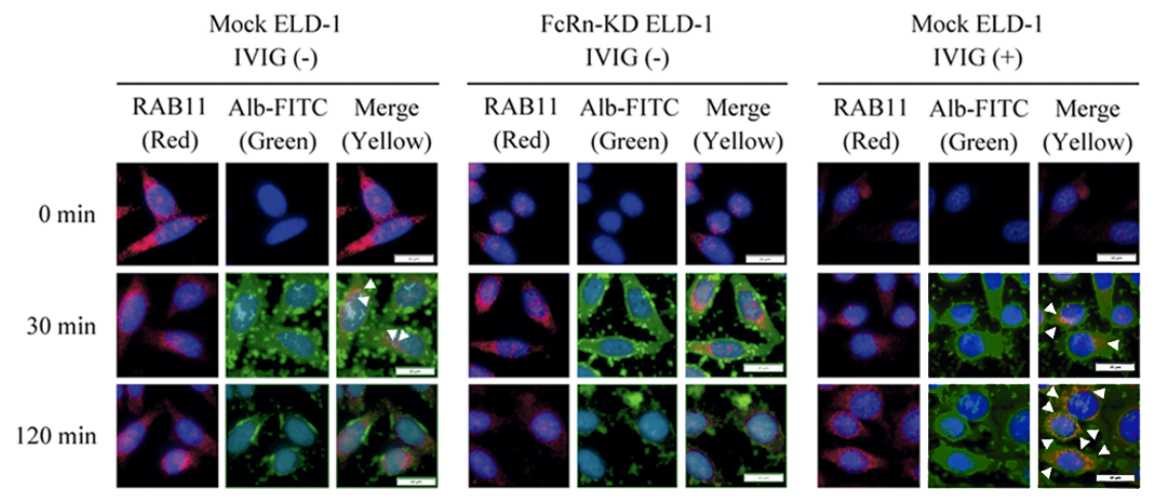



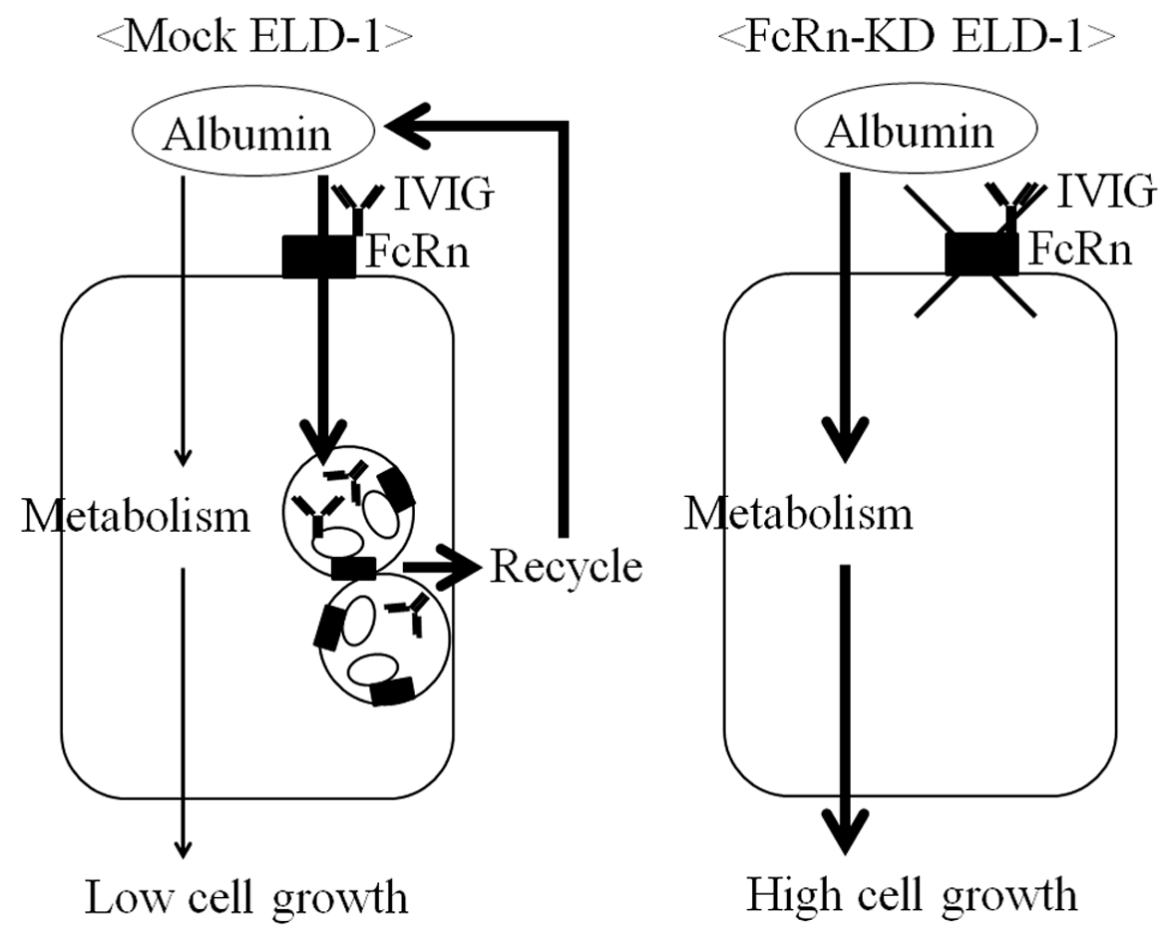

High cell growth 